\title{
HOME CARE IN THE REPUBLIC OF MOLDOVA: THE CHALLENGES FOR HEALTH AND SOCIAL POLICIES
}

\section{Diana CHEIANU-ANDREI ${ }^{1}$, PhD in Sociology, Associate Professor, State University of Moldova}

Home care responds to people's health and social needs by offering quality services at the recipient's residence. Demand for these services is steadily increasing, especially due to the aging population. The purpuse of this study is to analyze the situation in the field of home care in the Republic of Moldova. The study is based on a methodological approach focused on the analysis of the normative framework, the opinions of the service providers (public and private), but also of the representatives of the local public authorities, including the beneficiaries. Quantitative and qualitative research methods have been used. Sociological survey based on a questionnaire was applied to 84 home care providers from 23 out of 35 Moldovan administrative territorial units. In-depth individual interviews were conducted with 2 categories of people: 20 home care beneficiaries and 24 mayors. The results of the assessment reveal shortcomings and achievements in the field of home care in the Republic of Moldova and gives recommendations for governmental and local authorities, public and private providers in order to develop home care services and policies in the field of home care, organization of advocacy activities.

Keywords: home care, health policies, social policies, challenges, social home-based care, medical home-based care, providers, beneficiaries.

Îngrijirea la domiciliu răspunde la necesităţile de sănătate şi cele sociale ale oamenilor prin oferirea de servicii calitative acolo unde beneficiarul trăiește. Cererea faţă de aceste servicii este în continuă creştere, în mod special datorită procesului de îmbătrânire a populaţiei. Scopul acestui studiu este de a analiza situaţia în domeniul îngrijirii la domiciliu în Republica Moldova. Studiul dat are la bază o abordare metodologică axată pe analiza cadrului normativ, opiniile prestatorilor de servicii (publici şi privaţi), dar şi ale reprezentanţilor autorităţilor publice locale, inclusiv a beneficiarilor. S-au utilizat metode cantitative și calitative de cercetare. Ancheta sociologică pe bază de chestionar a fost aplicată la 84 de prestatori de servicii de îngrijire la domiciliu din cele 23 din 35 de unităţi administrativ teritoriale ale Moldovei. Interviuri individuale aprofundate au fost realizate cu 2 categorii de persoane: 20 de beneficiari ai serviciilor de îngrijire la domiciliu și 24 de primari. Rezultatele evaluării relevă deficiențele și realizările din domeniul îngrijirii la domiciliu în Republica Moldova şi prezintă recomandări destinate autorităţilor guvernamentale și locale, prestatorilor publici și privaţi pentru dezvoltarea serviciilor şi politicilor în domeniul îngrijirii la domiciliu, organizarea activităţilor de advocacy.

Cuvinte-cheie: îngrijire la domiciliu, politici medicale, politici sociale, provocări, îngrijire socială la domiciliu, îngrijire medicală la domiciliu, prestatori, beneficiari.

Уход на дому отвечает медицинским и социальным нуждам людей, предлагая качественные услуги там, где живет получатель. Спрос на эти услуги неуклонно растет, особенно из-за старения населения. Целью данного исследования является анализ ситуации в сфере ухода на дому в Республике Молдова. Исследование основано на методологическом подходе, ориентированном на знание ситуации в сфере услуг по уходу на дому, на основе анализа нормативной базы, мнений поставщиков услуг (государственных и частных), а также представителей местных органов власти, включая бенефициаров. Были использованы количественные и качественные методы исследования. Социологический опрос проводился среди 84 поставщиков услуг по уходу на дому в 23 из 35 административно-территориальных единиц Молдовы. Индивидуальные углубленные интервью были проведены с 2 категориями 
людей: 20 получателями услуг по уходу на дому и 24 мэрами. Результаты исследования выявляют недостатки и достижения в области ухода на дому в Республике Молдова и предлагают рекомендации для государственных и местных органов власти, государственных и частных поставщиков услуг для развития политики в области ухода на дому, организации адвокационных мероприятий.

Ключевые слова: уход на дому, медицинская политика, социальная политика, проблемы, социальный уход на дому, домашняя медицинская помощь, поставщики, бенефициары.

DOI: https://doi.org/10.36004/nier.es.2019.1-08

JEL Classification: I310, I390

UDC: 364.2 (478)

\section{Home care: an overview}

Home care aims at satisfying people's health and social needs in their home by providing appropriate and high-quality home-based health care and social services, by formal and informal caregivers, with the use of technology when appropriate, within a balanced and affordable continuum of care [1]. Life expectancy has risen sharply in the European countries in the last few decades. The proportion of older people in the general population is increasing steadily and it is predicted to rise still further in the coming decades. This will mean increasing rates of care-dependent older people [2, p.1-2]. The next decades will also see dramatic changes in the needs of those with health diseases, as the leading cause of disability and death. A variety of people with chronic conditions may be in the situation to stay at home given difficulties in mobility, and dependent children with severe health problems or people with mental disorders may also require home care.

Sociodemographic change and mobility trends affect home care needs. The break-up of the traditional large family group and other sociological trends, such as urbanization, complicate the situation. Family groups are often intact in rural areas, with many generations living in a household and family members taking care of the older or disabled family members. Urban communities are different, with small family units, limited living space and the younger generations often moving away from their families because of work commitments. All these factors increase the likelihood of today's and future generations needing additional care that their relatives are unlikely to provide and place a major responsibility on all levels of government: national, regional or district and especially municipal, where home care is applied in practice [3].

Home care as a concept is not clear, which may lead to uncertainty in its application and in the training of those working in home care [4, p.861]. Home care can be defined as an array of health and social support services provided to clients in their own residence. Such coordinated services may prevent, delay or be a substitute for temporary or long-term institutional care. The concept comprises a comprehensive field of actions and gives no clear understanding of the objectives of home care and who is the recipient, what is actually done and what effects would be desirable. A more specific clarification of the concept may be helpful in education and practice [5, p.9].

The home care concept, how it appears in practice, what are the underlying goals and when it is applied, who its recipients are and what it consists of was analyzed by Meleis A. [6]. The author specifies that home care as a phenomenon seems to be best understood as activities representing the whole span of care activities from the primary prevention to the palliative care at the end of the life. As home care represents a large field of care activities, it might be appropriate to use home care as an umbrella concept with different subconcepts describing the level of the activity and objectives in focus.

Thome B., Dykes A.-K., Hallberg I. (2003) done a review of the empirical literature for the description of home care as a phenomenon and as a concept, especially with regards to who the care recipients are, what actions and assessments are performed and what effects are achieved for the care recipients in terms of functional health status and quality of life. The authors concluded that home care as phenomenon is the care provided by professionals to a person in his/her own home with the ultimate goal being not only to contribute to his/her life quality and functional health status, but also to replace hospital care with care in the home for societal reasons and covering a wide range of activities from preventive visits to end/of life care [7, p.871]. 
Genet N., Boerma W., etc. (2011) had done a systematic literature review of home care in Europe. The authors focus on 74 relevant studies, providing information on characteristics of home care recipients and the organization of home care in 18 countries. The main conclusions reveal that home care systems appeared to differ both between and within countries. Many studies focus only on the one aspect of home care system and little information emerged on home care in Eastern Europe. The authors highlight the need for more scientific publications on home care, especially for comprehensive and more complete insight [8].

The overall objective of the paper is to analyse the home care in the Republic of Moldova, to assess the home care service providers (private and public) and the needs of the population in such services, to help Moldovan authorities develop evidence-based policies and contribute to the sustainable home-based care development.

The article is based on comprehensive analysis of home-based care in the Republic of Moldova. The methodology combines local approach with international experience and relied on primary and secondary data sources. Thus, a desk review was conducted on legal framework and analysis of provision home-based care characteristics and models. Additional to these data, field information was collected from home-based care service providers, service beneficiaries and local public authorities (LPA) at I and II levels. The assessment is mixing quantitative and qualitative research methods. The survey sample comprised 84 home-based care service providers from 23 of 35 administrative territorial units. The qualitative research involved 2 target groups: 20 beneficiaries of home care services and 23 LPA representatives.

Types of home care services

In the Republic of Moldova, the concept of home care gives no clear understanding and comprises different types of home care services: social home-based care services, medical home-based care services and integrated home-based care services (Are not regulated by normative acts.), (see Figure 1). One way of understanding the concept of home care is to describe the phenomenon, how it appears in practice, how it is provided, what are the underlying goals, who are recipients.

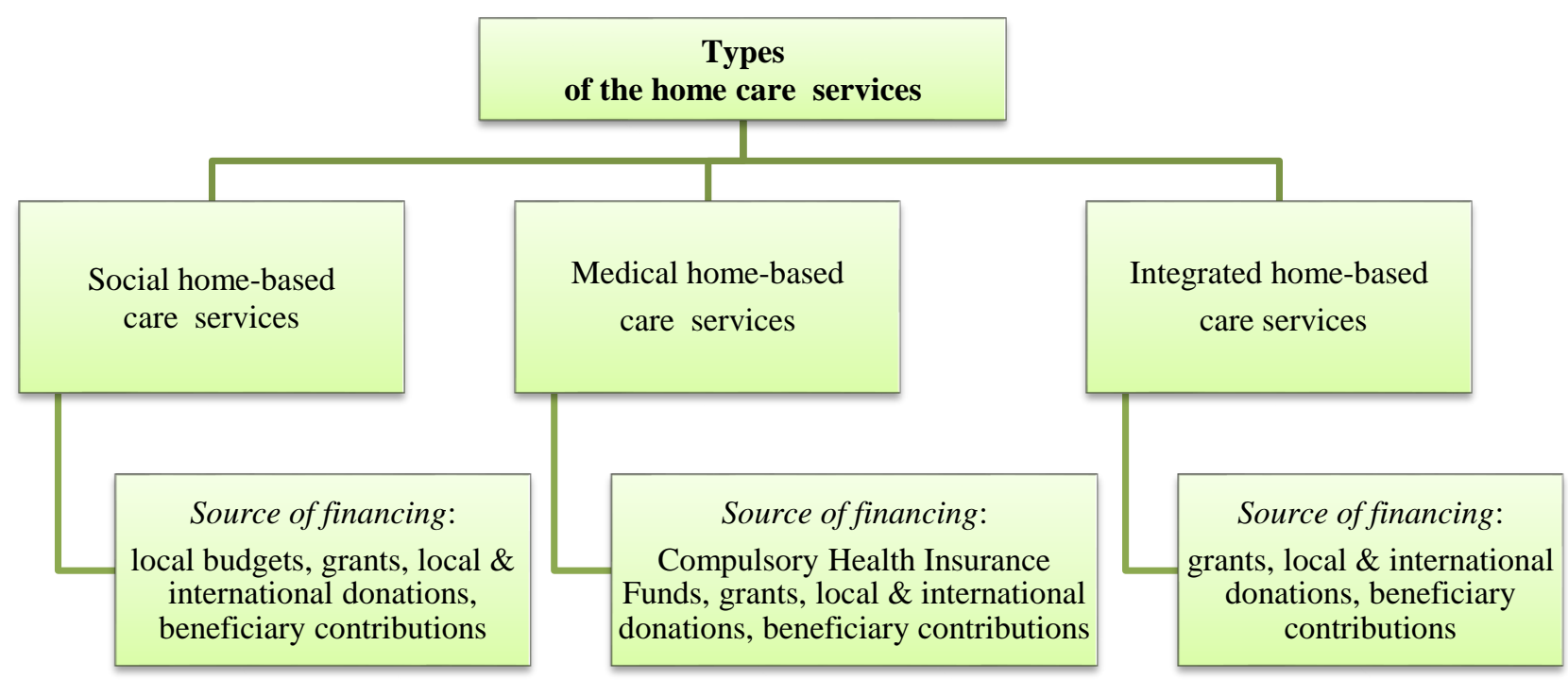

Figure 1. Home care services types and sources of funding

Source: Author's analysis.

The social home-based care is one of the oldest social services in the Republic of Moldova. Social workers were the first specialists to be employed in the social assistance sphere to provide social home-based care services. Within the first years of the Republic of Moldova's independence, social workers providing social home-based care services were employed by the National Social Insurance House and with the creation of Territorial Units of Social Assistance (TUSA) in 1998, they were subordinated to the last. Gradually, social home-based care service has been developed and private providers have emerged alongside with public providers. 
The bedrock of medical home-based care services, in the Republic of Moldova was put in December 1999 by the Catholic Religious Mission "Caritas-Moldova", Interconfessional Society of Christian Doctors "Emanuil" and the Civil Society Organization (CSO) "Nursing Association from Republic of Moldova", with the support of "CORDAID" organization, Holland, that implemented the first pilot project on home care. An essential step in the development of the medical home-based care services was the approval in 2007 of the Unique Compulsory Health Insurance Program and the inclusion of medical home-based care services as a form of medical assistance, alongside with prehospital emergency, primary, ambulatory and hospital care [9]. The section 6 of this Program stipulates that insured bedridden patients are entitled to medical home-based care services. These services are provided individually by service providers contracted by the National Health Insurance Company (NHIC) according to the law. The first service providers were contracted in 2008.

The social home-based care service [10] represents a public (established within territorial structures of social assistance) or private service (created by foundations, private non-profit organizations, registered according to the law, dealing with social sector). The purpose of the service is to provide quality social home-based care services as to ensure better quality of the beneficiaries' life. The providers of social home-based care services are presented in the Figure 2.

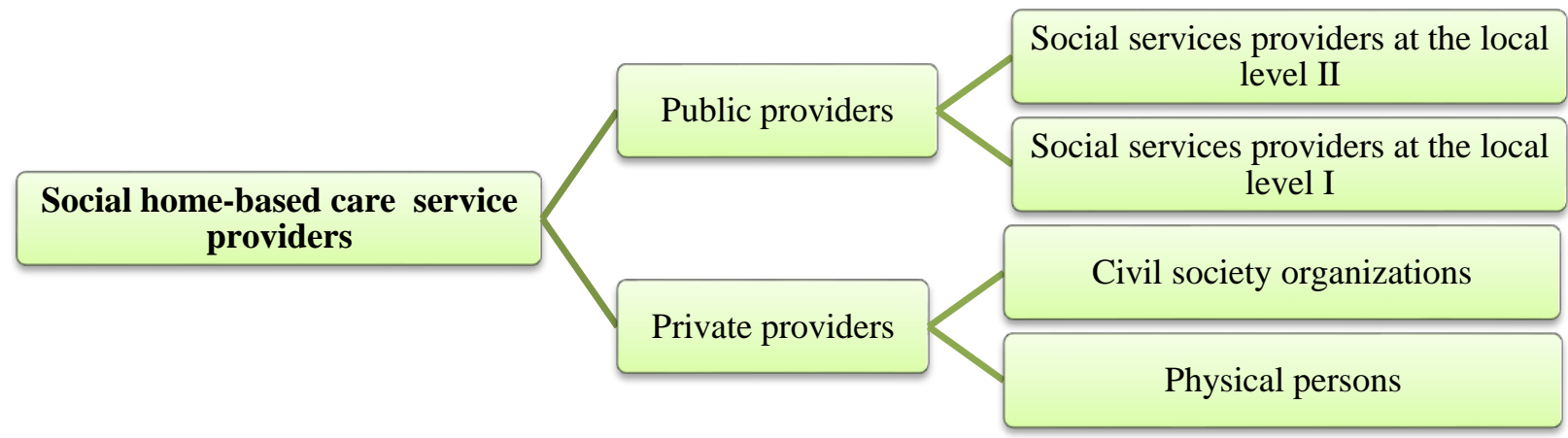

Figure 2. Social home-based care service providers

Source: Author's analysis.

Medical home-based care service represents a public or private service provided, in accordance with the law in force, by a healthcare institution, irrespective of its type of ownership and legal form of organization, usually CSOs (the model in which the "medical" component stays a part of the health care system and the "social" component of the social system exist in the Czech Republic, Slovak Republic, Romania). The providers of medical home-based care service are presented in Figure 3. The purpose of medical home-based care services is to provide the patient with qualified, dignified and appropriate care according to his individual needs, in order to stimulate the rehabilitation, maintenance and/or rehabilitation of the health condition and reduce the negative effects of the disease. The public medical home-based care service providers are mainly medical public institutions and a few private institutions. In 2017 NHIC contracted, for the provision of medical home-based care services, 131 state medical institutions and other 9 private institutions.

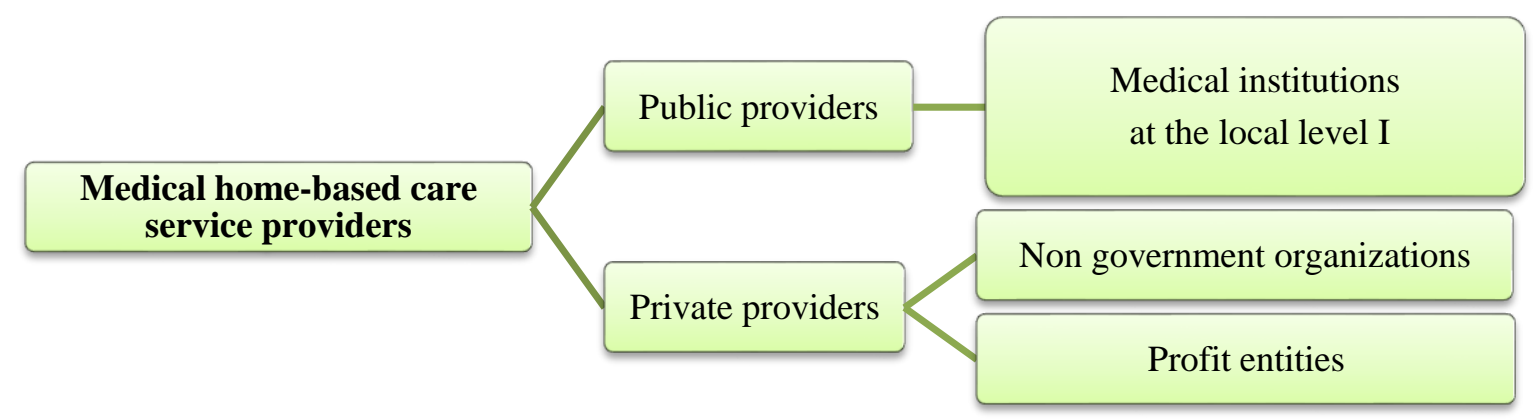

Figure 3. Medical home-based care service providers

Source: Author's analysis. 
There are no legal provisions regarding the integrated home-based care services, neither standards (the model in which social and medical are almost fully integrated is the "Scandinavian model" - Sweden, Finland, Norway). However, certain service providers, especially the CSOs, but also some public institutions, operate within this notion. Integrated services provide, as per particular needs, both social and medical home-based care services or in other words, the same beneficiary receives support from a social worker and from a medical assistant, but not always with common coordination of their efforts.

\section{Characteristics of home-based care service providers}

The mapping of home-based care service providers, reveals a wide range of service providers according the organization and legal status: medical institutions, TUSA, CSOs, providers appointed by LPA ${ }^{1}$, including profit entities. Most of the service providers are public institutions (medical institution, TUSA), followed by CSOs.

From the perspective of the geographical coverage, most of the home-based care service are provided at the community/first level (50), followed by those operating at the district/second level (29), regional (2) and national providers (3). Thus, public medical institutions usually provide home-based care at community level, TUSA - at the district level (except Administrative Territorial Unit Gagauzia, where TUSA does not provide social home-based care services, but the mayoralties), providers appointed by LPA at both, community level and district, profit entity at the district level. The CSOs are diverse and operate in different geographical areas - starting with the community, district, regional and finishing with national coverage (Table 1).

Table 1

Home-based care providers according to the geographical coverage, number

\begin{tabular}{|c|c|c|c|c|c|c|}
\hline \multirow{2}{*}{$\begin{array}{c}\text { Geographical } \\
\text { area }\end{array}$} & $\begin{array}{c}\text { Medical } \\
\text { institutions }\end{array}$ & TUSA & CSO & $\begin{array}{c}\text { Provider appointed } \\
\text { by LPA }\end{array}$ & $\begin{array}{c}\text { Profit } \\
\text { entity }\end{array}$ \\
\cline { 2 - 7 } & Regional & - & - & 3 & - & - \\
\cline { 2 - 7 } & District & - & - & 2 & - & - \\
\cline { 2 - 7 } & Local & 3 & 22 & 4 & 1 & - \\
\hline \multirow{2}{*}{ Total } & & 39 & - & 8 & 1 & $\mathbf{1}$ \\
\hline
\end{tabular}

Source: Author's analysis.

According the types of provided home care, it was established that most of providers offer medical services, followed by those providing social services and only a few provide integrated services (Table 2). The CSOs, most often, provide integrated home-based care services. However, some medical institutions and TUSA follow their example. The home-based care services depend on the beneficiaries' needs and possibility of provider to respond to these needs.

Table 2

Types of home-based care providers, number

\begin{tabular}{|l|c|c|c|c|c|}
\hline $\begin{array}{c}\text { Type of home- } \\
\text { based care } \\
\text { services }\end{array}$ & $\begin{array}{c}\text { Medical } \\
\text { institutions }\end{array}$ & TUSA & CSO & $\begin{array}{c}\text { Provider } \\
\text { appointed by } \\
\text { LPA }\end{array}$ & Profit entity \\
\hline Social & - & 20 & 9 & 1 & - \\
\hline Medical & 39 & - & 1 & - & 1 \\
\hline Integrated & 3 & 2 & 7 & 1 & - \\
\hline \multicolumn{1}{|c|}{ Total } & $\mathbf{4 2}$ & $\mathbf{2 2}$ & $\mathbf{1 7}$ & $\mathbf{2}$ & $\mathbf{1}$ \\
\hline
\end{tabular}

Source: Author's analysis.

1 There are 2 situations in this case: home-based care service provider appointed by the LPA of the II level and the provider appointed by the LPA of the I level. Social workers from Administrative Territorial Unit Gagauzia are employed within the municipality, not the TUSA. The representative of LPA of the II level believes it is more correct that social home-based care services is within TUSA ensuring in this way a methodological control and increasing social home-based care quality. 
According to home-based care service for free or for a fee, out of the 84 service providers, 74 render free home-based care services, 3 from 74 providers render home-based care services for free and for a fee, while 10 providers offer only co-paid services ${ }^{1}$ (Table 3 ).

Table 3

Home-based care service providers ensuring services for free or for a fee, number

\begin{tabular}{|l|c|c|c|}
\hline & Free services & Co-paid services & Paid services \\
\hline Medical institutions & 42 & - & - \\
\hline TUSA & 22 & - & 3 \\
\hline CSO & 7 & 10 & - \\
\hline Provider appointed by LPA & 2 & - & - \\
\hline Profit entities & 1 & - & - \\
\hline \multicolumn{1}{r|}{ Total } & $\mathbf{7 4}$ & $\mathbf{1 0}$ & $\mathbf{3}$ \\
\hline
\end{tabular}

Source: Author's analysis.

The number of service beneficiaries differs from one provider to another, including from one type of service to another. Thus, the research data reveal that medical institutions provide services to a minimum of 2 persons (Health Centers from rural areas) and to maximum - 107 persons (20 beneficiaries on average). The number of CSOs' beneficiaries is much higher, from at least 8 persons to maximum 2100 ( 472 beneficiaries on average). TUSA registered the highest number of beneficiaries, from a minimum of 298 persons to 2171 persons (636 beneficiaries on average) (see Table 4).

Table 4

The number of beneficiaries per home-based care providers, number ${ }^{2}$

\begin{tabular}{|c|c|c|c|}
\hline & Medical institutions & TUSA & CSO \\
\hline Mean & 20 & 636 & 472 \\
\hline Median & 10 & 522 & 142 \\
\hline Mode & 5 & 412 & 44 \\
\hline Minimum & 2 & 298 & 8 \\
\hline Maximum & 107 & 2171 & 2100 \\
\hline
\end{tabular}

Source: Author's analysis.

Almost every $4^{\text {th }}$ institution ${ }^{3}$ of those 84 participating in assessment, asserted that they have restrictions in providing home-based care services. ${ }^{4}$ Most restrictions were mentioned by medical institutions, followed by TUSA and CSOs. Medical institutions have contracted an exact number of visits - 36 visits per beneficiary (72 visits in special cases), visits exceeding this number are not paid. Some CSOs also have to provide services to beneficiaries in rotation (once every 3 or 6 months) at the donor's request or according to their own regulations. Maintaining a fixed period for home-based care service provision is targeted to serve much more beneficiaries requiring home-based care services. The number of those in need is high and it is still growing, triggered by the ageing of the population (the national ageing index in 1980 was 10.7\%, while in 2018 it reached 17.7\%) [11].

Service providers revealed both, advantages and disadvantages of a fixed period for service provision to both, providers and beneficiaries (see Table 5). Based on some arguments, certain CSOs

${ }^{1}$ An amount is paid by the beneficiary, a part by - LPA and the rest by - CSO "CASMED" or an amount is paid by the beneficiary and the rest by different CSOs.

2 Service providers appointed by LPAs and businesses will not be assessed, due to their small number. The profit entity provided services in 2016 to 101 persons. The service provider appointed by LPA that operates in the district, provided services to 110 in 2016, while that working in the community - to 58 persons.

322 institutions.

4 There are restrictions regarding free services. 
manage to get the opportunity to extend the provision of home-based care services. As arguments serve: (i) lack of a positive evolution or worsening of the beneficiary's health, (ii) beneficiary's impossibility to take care of himself, (iii) people of the waiting list are less disadvantaged. The possibility of extending the period of home-based care provision may be negotiated for private providers or in the case of partially paid services.

Table 5

\section{Advantages and disadvantages of a fixed period for service provision}

Advantages for institution $\quad$ Advantages for beneficiaries

\begin{tabular}{|l|l|}
\hline - Big number of beneficiaries, & - Improvement of health condition in a short time, \\
- Rigorous planning and well-established individual & - Motivation of the beneficiary, including the family, \\
plan, & - Social inclusion, \\
- High level of specialist's responsibility to provide & - Prevention of institutionalization. \\
$\begin{array}{l}\text { quality services for a period, } \\
\text { - Development of intersectoral collaboration, }\end{array}$ & \\
- Do not develop dependence. & \multicolumn{1}{|c}{ Disadvantages for beneficiaries } \\
\hline \multicolumn{1}{|c|}{ Disadvantages for institution } & - Worsening of the health condition, \\
\hline $\begin{array}{l}\text { - In } 36 \text { visits / } 6 \text { months, the complete } \\
\text { improvement of the situation is not achieved, } \\
\text { - Increased workloads for specialists, } \\
\text { - Job burnout, }\end{array}$ & $\begin{array}{l}\text { - Isolation, marginalization, loss of hope in a bright } \\
\text { - Comorrow. }\end{array}$ \\
\hline
\end{tabular}

Source: Author's analysis.

\section{Geographical coverage of home-based care services}

From the geographical perspective the analysis reveals national coverage with social home-based care of elderly people officially registered single and people with disabilities without support from children, extended family and other people (friends, relatives, neighbors), with the exception of very small villages. TUSA from all administrative territorial units try to provide social home-based care services in every village according to the normative documents in force. Authorities from one administrative territorial unit have developed social home-based care for people requiring this type of services but people cannot receive it as they do not meet the requirements of the Government Decision no. 1034.

Medical home-based care are distributed non-uniformly. For example, in 2017 NHIC contracted 131 state medical institutions (Territorial Medical Associations (5), Health Centers (126) of 258 public health institutions and other 9 private institutions (6 CSOs, including 2 religious organizations and 1 profit entity).

In general, just half $(51 \%)$ of public health institutions were contracted for the provision of medical home-based care services, when speaking about the geographical coverage, there are administrative territorial units covered by more providers and administrative territorial units served only by one or no one. The number of contracted visits groups by medical home-based care service providers (4 categories) is presented below (see Table 6).

Number of visits contracted by service providers from NHIC in 2017

\begin{tabular}{|l|c|c|c|}
\hline $\begin{array}{c}\text { Number of contracted } \\
\text { visits }\end{array}$ & Number of providers & $\begin{array}{c}\text { Type of providers } \\
\text { according the legal } \\
\text { form of organization }\end{array}$ & $\begin{array}{c}\text { Type of provider, } \\
\text { according the location }\end{array}$ \\
\hline From 12 to 299 visits & 107 & Health Centers & Mostly from rural areas \\
\hline $\begin{array}{l}\text { From } \mathbf{3 0 0} \text { to } 999 \\
\text { visits }\end{array}$ & 25 & $\begin{array}{c}\text { 20 Health Centers and 5 } \\
\text { CSOs }\end{array}$ & $\begin{array}{c}\text { Town or administrative } \\
\text { territorial units, region }\end{array}$ \\
\hline $\begin{array}{l}\text { From } \mathbf{1 0 0 0} \text { to } \mathbf{2 2 3 0} \\
\text { visits }\end{array}$ & 7 & $\begin{array}{c}\text { medical institutions, } \\
\text { 2 CSOs, 1 profit entity }\end{array}$ & $\begin{array}{c}\text { Town or administrative } \\
\text { territorial units, region }\end{array}$ \\
\hline $\mathbf{1 4 9 4 0}$ visits & 1 & 1 CSO & Town \\
\hline
\end{tabular}

Source: Author's analysis. 
These data reveal that there are no well-defined criteria for contracting a certain number of visits for medical home-based care services. The number of people is not taken into account when contracting service providers thus leading to discrepancies. For example, of the total amount of funds allotted for medical home-based care in 2017, about 35\% are given to the municipality of Balti, and only $10 \%$ to the municipality of Chisinau which is 5 times bigger than Balti in terms of the population number and other 55\% to the rest of localities of the Republic of Moldova. The fact that the municipality of Balti representing 5\% of the total population of the Republic of Moldova absorbs about $35 \%$ of the funds denotes that (i) there are people requiring medical home-based care services, (ii) the lack of a mechanism to ensure the coverage with medical home-based care services, (iii) medical institutions are not encouraged to sign contracts with the NHIC on medical home-based care services or (iv) the current cost covered by the NHIC discourages potential medical home-based care providers.

The geographical distribution of private home-based care service providers (CSOs and profit entities) is also not homogeneous. The distribution is frequently determined by LPA's readiness to collaborate with CSOs in developing home-based care.

Criteria for admission to home-based care services

TUSA provide social home-based care services according to the Government Decision no. 1034. Free services are offered to elderly people who have reached the standard retirement age and people with disabilities without support from children, the extended family and other people (friends, relatives, neighbours). However, lack of children/support from children stipulated in the law is actually interpreted mainly as childless.

All accredited public and private providers provide medical services to beneficiaries in accordance with the Regulation and Standards related to medical home-based care set forth in the Orders of the Ministry of Heath no. 855 of 29.07.2013 and no. 851 of 29. 07.2017. The person has to meet a few criteria to benefit from services: (i) to have medical insurance, (ii) to have a recommendation from the family doctor / specialist, (iii) to reside on the territory served by the medical institution.

The admission to home-based care within the CSOs is based on specific criteria of donors. The basic request from donors is to include the most vulnerable in home-based care service. Usually, individuals are accepted based on certificates from TUSA, LPA (wage/pension, family composition), medical institution (referral from family doctor/specialized doctor from hospital/health center), without infections or mental illness. CSOs provide home-based care services to people that do not benefit from such kind of services from public or private providers.

There are differences in the characteristics of the beneficiaries from one type of providers to another, determined by the peculiarities of institutions providing services and the normative documents. TUSA beneficiaries are more often women, single and from rural area. The evaluation data indicate that medical home-based care services are more gender balanced, targeted at people with disabilities and are particularly accessible to people from urban area. CSOs are oriented to the categories of beneficiaries that are not covered by public medical institutions and TUSA, thus increasing the number of men, people under the age of 65 , those with relatives.

offer and demand for home-based care services

The analysis of home-based care services from geographical perspective reveals a national coverage with social home-based care services of elderly registered as single and people with disabilities without support of children, extended families and other people. Medical home-based care services are not distributed uniformly. Half of public health institutions from the local level I were contracted by NHIC for the provision of medical home-based care services. When speaking about the geographical coverage, with medical home-based care services, there are administrative territorial units covered by more providers and administrative territorial units served only by a few or no one. The analysis of private home-based care service providers (CSOs and profit entities), is also not homogeneous. The distribution is frequently determined by LPA's readiness to collaborate with CSOs in developing home-based care.

So, the home-based care services are not available to all those who needs them. Home-based care services are not accessible because some persons who need them do not comply with the 
normative provisions for admission to such services. Also, home-based care services, especially medical services, are not provided in all localities of the Republic of Moldova. Home-based care services offered by CSOs are not available in all localities of the country. Lonely old people abandoned by their children are disadvantaged and deprived of home-based care services.

Assessment has allowed to made estimations about people who need home-based care services. The estimated number of people who need home-based care social services is 33915 people. Currently, social home-based care services are offered for about $2 / 3$ of those who need it. The estimated number of people in need of medical home-based care services is 13972 people. Currently, medical home-based care services are offered to about 18 percent of those who need it.

\section{Home-based care service models}

The assessment revealed various models of home-based care service provision. Within each type of home-based care service (medical, social, integrated), several models were identified based on 9 main criteria: (i) type of provided service, (ii) legal form of organization of the provider, (iii) human resources involved in the provision of services, (iv) working mode of the provision of home-based care services, (v) type of beneficiaries, (vi) criteria for admission to service, (vii) duration of service provision, (viii) area of service delivery (ix) cost of the service paid by the beneficiary.

The models of social home-based care services have in common only the development of partnerships and, with few exceptions, the working hours. Social models are designed to complement each other (see Table 7) which is a major advantage. Thus, local private providers, or even the public ones, target vulnerable beneficiaries that do not meet the criteria of the Government Decision no.1034 of 31.12.2014.

Table 7

Models of social home-based care services delivery

\begin{tabular}{|c|c|c|c|c|}
\hline $\begin{array}{c}\text { Criteria for } \\
\text { differentiation }\end{array}$ & Model A & Model B & Model C & Model D \\
\hline $\begin{array}{l}\text { Type of provided } \\
\text { service }\end{array}$ & \multicolumn{4}{|c|}{ Social home-based care services } \\
\hline $\begin{array}{l}\text { Form of } \\
\text { organization }\end{array}$ & Public & Private (CSOs) & Public & Public \\
\hline $\begin{array}{l}\text { Human } \\
\text { resources }\end{array}$ & $\begin{array}{l}\text { Head of the service, } \\
\text { Social workers }\end{array}$ & $\begin{array}{l}\text { Head of the service, } \\
\text { Social assistant, } \\
\text { Social workers }\end{array}$ & Social workers & $\begin{array}{l}\text { Head of the service, } \\
\text { social workers }\end{array}$ \\
\hline Working mode & $\begin{array}{c}8 \text { hours per day, on } \\
\text { Saturdays and Sundays } \\
\text { at request }\end{array}$ & $\begin{array}{c}8 \text { hours per day } 5 \text { days } \\
\text { a week }\end{array}$ & $\begin{array}{c}8 \text { hours per day } 5 \text { days } \\
\text { a week }\end{array}$ & $\begin{array}{l}8 \text { hours per day } 5 \text { days } \\
\text { a week }\end{array}$ \\
\hline $\begin{array}{l}\text { Type of } \\
\text { beneficiaries }\end{array}$ & $\begin{array}{c}\text { Categories enlisted in } \\
\text { the pt. } 11 \text { and } 12 \text { of the } \\
\text { Regulatory Framework } \\
\text { on Home based Social } \\
\text { Care Services, } \\
\text { Government Decision } \\
\text { no.1034 }\end{array}$ & $\begin{array}{l}\text { Categories enlisted in } \\
\text { the pt. } 11 \text { and } 12 \text { of the } \\
\text { Regulatory Framework } \\
\text { on Home based Social } \\
\text { Care Services, } \\
\text { Government Decision } \\
\text { no.1034, vulnerable } \\
\text { people that have not } \\
\text { reached the retirement } \\
\text { age }\end{array}$ & $\begin{array}{l}\text { Vulnerable people that } \\
\text { have reached the } \\
\text { retirement age }\end{array}$ & $\begin{array}{c}\text { Categories enlisted in } \\
\text { the pt. } 11 \text { of the } \\
\text { Regulatory Framework } \\
\text { on Home based Social } \\
\text { Care Services, } \\
\text { Government Decision } \\
\text { no.1034 }\end{array}$ \\
\hline $\begin{array}{l}\text { Criteria for } \\
\text { admission to } \\
\text { service }\end{array}$ & $\begin{array}{l}\text { Based on the eligibility } \\
\text { criteria for care } \\
\text { services and the results } \\
\text { of the assessment of } \\
\text { applicant's care needs }\end{array}$ & $\begin{array}{l}\text { Based on the eligibility } \\
\text { criteria for care } \\
\text { services and the results } \\
\text { of the assessment of } \\
\text { applicant's care needs. } \\
\text { Referral mechanism } \\
\text { applied by TUSA, LPA, } \\
\text { other relevant } \\
\text { institutions. } \\
\text { Beneficiary's own } \\
\text { request or request } \\
\text { from his/her } \\
\text { representative }\end{array}$ & Request from LPA & Request from LPA \\
\hline
\end{tabular}




\begin{tabular}{|c|c|c|c|c|}
\hline $\begin{array}{c}\text { Criteria for } \\
\text { differentiation }\end{array}$ & Model A & Model B & Model C & Model D \\
\hline $\begin{array}{l}\text { The duration of } \\
\text { service provision }\end{array}$ & $\begin{array}{l}\text { Untill the decease, } \\
\text { improvement of the } \\
\text { beneficiary's condition } \\
\text { or the occurrence of } \\
\text { circumstances that } \\
\text { makes the person } \\
\text { ineligible }\end{array}$ & $\begin{array}{l}\text { 3-6 months, till the } \\
\text { improvement of the } \\
\text { beneficiary's condition } \\
\text { or the occurrence of } \\
\text { circumstances that } \\
\text { makes the person } \\
\text { ineligible }\end{array}$ & $\begin{array}{l}\text { Untill the decease, } \\
\text { improvement of the } \\
\text { beneficiary's condition } \\
\text { or the occurrence of } \\
\text { circumstances that } \\
\text { makes the person } \\
\text { ineligible }\end{array}$ & $\begin{array}{l}\text { Untill the decease, } \\
\text { improvement of the } \\
\text { beneficiary's condition } \\
\text { or the occurrence of } \\
\text { circumstances that } \\
\text { makes the person } \\
\text { ineligible }\end{array}$ \\
\hline $\begin{array}{l}\text { Area of service } \\
\text { delivery }\end{array}$ & District & Local & District & Local \\
\hline $\begin{array}{l}\text { Cost of the } \\
\text { service paid by } \\
\text { the beneficiary }\end{array}$ & $\begin{array}{l}\text { Free of charge } \\
\text { For a fee }\end{array}$ & $\begin{array}{c}\text { Free of charge } \\
\text { Symbolic co-payment } \\
\text { of the cost of the } \\
\text { service }\end{array}$ & Free of charge & Free of charge \\
\hline
\end{tabular}

\section{Source: Author's analysis.}

The strong points of the model A-social consist in provision of funding from the LPA budget and the presence of social workers in almost all localities of the Republic of Moldova. The weak points of the model lie in the fact that vulnerable people requiring home-based care are not admitted to services if they do not meet the provisions of the Government Decision no. 1034. The opportunity of this model is the development of services provided for a fee that could be delivered to beneficiaries with a better financial situation but still requiring such services. Model B-social and C-social are designed to complement the gaps of the model A, through undertaking certain responsibilities by LPA (model C) or by assigning responsibilities to both, LPA and beneficiaries (model B). Model D-social exists only in the Gagauzia and is the archaic model from the Soviet Union period. The gaps of this model lie in the fact that social workers employed by LPA of the $1^{\text {st }}$ level are not part of a service evaluation and monitoring system.

Medical home based-care models have much in common (see Table 8).

Table 8

Models of medical home-based care services delivery

\begin{tabular}{|c|c|c|c|c|c|}
\hline $\begin{array}{c}\text { Criteria for } \\
\text { differentiation }\end{array}$ & Model A & Model B & Model C & Model D & Model E \\
\hline $\begin{array}{l}\text { Type of provided } \\
\text { service }\end{array}$ & \multicolumn{5}{|c|}{ Medical home-based care services } \\
\hline $\begin{array}{l}\text { Form of } \\
\text { organization }\end{array}$ & Public & $\begin{array}{c}\text { Private (business } \\
\text { entity) }\end{array}$ & Private (CSO) & Private (CSO) & Private (CSO) \\
\hline $\begin{array}{l}\text { Human } \\
\text { resources }\end{array}$ & $\begin{array}{l}\text { Doctors, medical } \\
\text { assistants }\end{array}$ & $\begin{array}{l}\text { Doctor, medical } \\
\text { assistants }\end{array}$ & $\begin{array}{l}\text { Doctor, medical } \\
\text { assistants }\end{array}$ & $\begin{array}{l}\text { Doctor, medical } \\
\text { assistants }\end{array}$ & $\begin{array}{l}\text { Doctor, medical } \\
\text { assistants }\end{array}$ \\
\hline Working mode & $\begin{array}{c}\text { Differ from } 2 / 4 \\
\text { hours to } 7 \text { hours } \\
\text { per day or a few } \\
\text { hours } 2-3 \text { days a } \\
\text { week }\end{array}$ & $\begin{array}{c}7 \text { hours per day, } \\
\text { on Saturdays and } \\
\text { Sundays at } \\
\text { request }\end{array}$ & $\begin{array}{l}7 \text { hours per day, } \\
\text { at request }\end{array}$ & $\begin{array}{l}7 \text { hours per day, } \\
\text { at request }\end{array}$ & $\begin{array}{l}7 \text { hours per day, } \\
\text { at request }\end{array}$ \\
\hline $\begin{array}{l}\text { Type of } \\
\text { beneficiaries }\end{array}$ & Insured people & Insured people & $\begin{array}{c}\text { Insured people, } \\
\text { uninsured people, } \\
\text { without identity } \\
\text { documents } \\
\text { inclusively }\end{array}$ & $\begin{array}{l}\text { Insured people, } \\
\text { uninsured people, } \\
\text { without identity } \\
\text { documents } \\
\text { inclusively }\end{array}$ & Insured people \\
\hline $\begin{array}{l}\text { Criteria for } \\
\text { admission to } \\
\text { service }\end{array}$ & $\begin{array}{l}\text { Family doctor's } \\
\text { recommendation } \\
\text { written in the } \\
\text { patient's medical } \\
\text { record }\end{array}$ & $\begin{array}{l}\text { Referral form } \\
\text { (form no. 027/e) } \\
\text { from the family } \\
\text { doctor or } \\
\text { specialist }\end{array}$ & $\begin{array}{c}\text { Referral form } \\
\text { (form no. 027/e) } \\
\text { from the family } \\
\text { doctor, specialist, } \\
\text { doctor employed } \\
\text { by the provider, } \\
\text { case referral from } \\
\text { TUSA or LPA, } \\
\text { including } \\
\text { patient's } \\
\text { individual request }\end{array}$ & $\begin{array}{c}\text { Referral form } \\
\text { (form no. 027/e) } \\
\text { from the family } \\
\text { doctor, specialist, } \\
\text { doctor employed } \\
\text { by the provider, } \\
\text { case referral from } \\
\text { TUSA or LPA, } \\
\text { including } \\
\text { patient's } \\
\text { individual request }\end{array}$ & $\begin{array}{c}\text { Referral form } \\
\text { (form no. 027/e) } \\
\text { from the family } \\
\text { doctor, specialist, } \\
\text { LPA }\end{array}$ \\
\hline
\end{tabular}




\begin{tabular}{|c|c|c|c|c|c|}
\hline $\begin{array}{l}\text { Criteria for } \\
\text { differentiation }\end{array}$ & Model A & Model B & Model C & Model D & Model E \\
\hline $\begin{array}{l}\text { The duration of } \\
\text { service provision }\end{array}$ & $\begin{array}{c}36 \text { visits, } \\
\text { sometimes } 72 \\
\text { visits }\end{array}$ & $\begin{array}{c}36 \text { visits, } \\
\text { sometimes } 72 \\
\text { visits }\end{array}$ & $\begin{array}{c}36 \text { visits, } \\
\text { sometimes } 72 \\
\text { visits contracted } \\
\text { from the NHIC. } \\
\text { Up to } 365 \text { visits } \\
\text { per year, } \\
\text { depending on the } \\
\text { current financial } \\
\text { resources of the } \\
\text { provider } \\
\text { (donations, } \\
\text { sponsorship, co- } \\
\text { financing) }\end{array}$ & $\begin{array}{c}36 \text { visits, } \\
\text { sometimes } 72 \\
\text { visits contracted } \\
\text { from the NHIC. } \\
\text { Up to } 365 \text { visits } \\
\text { per year, } \\
\text { depending on the } \\
\text { current financial } \\
\text { resources of the } \\
\text { provider } \\
\text { (donations, } \\
\text { sponsorship) }\end{array}$ & $\begin{array}{c}36 \text { visits, } \\
\text { sometimes } 72 \\
\text { visits }\end{array}$ \\
\hline $\begin{array}{l}\text { Area of service } \\
\text { delivery }\end{array}$ & Local & District & $\begin{array}{l}\text { Regional (more } \\
\text { Districts) }\end{array}$ & $\begin{array}{l}\text { Regional (more } \\
\text { Districts) }\end{array}$ & Local \\
\hline $\begin{array}{l}\text { Cost of the } \\
\text { service paid by } \\
\text { the beneficiary }\end{array}$ & Free of charge & Free of charge & $\begin{array}{l}\text { Free of charge, } \\
\text { a symbolic co- } \\
\text { payment of the } \\
\text { cost of the service }\end{array}$ & Free of charge & Free of charge \\
\hline
\end{tabular}

Source: Author's analysis.

Model A-medical addresses the insured people, but does not allow all insured people to benefit from such services (the evaluation study outcomes show that not all medical institutions contract medical home-based care services from NHIC). It can be explained by the small number of visits offered to medical institutions from rural areas and the low cost of a visit reimbursed by the NHIC. Model B-medical is a successful one, from the perspective of the working schedule - 7 hours per day, in this way meeting the beneficiaries' needs. This model aims to provide services to the large majority of insured beneficiaries from the district. Model C-medical has as advantage the opportunity to access the service -7 hours per day, admission to services of uninsured people, people without identity documents, multiple funding (NHIC, donors, LPA), including the empowerment of beneficiaries to come up with a symbolic co-payment, possibility to provide services for a period of time up to one year. Model D-medical differs from model C-medical in the absence of the symbolic co-payment from the beneficiaries' side. Model E-medical differs from models C-medical and D-medical in the existence of funding exclusively from the NHIC, provision of services for 36/72 visits and limited collaboration with authorities.

The integrated models meet a wider variety of needs (social, medical) through the presence of a diverse team of professionals. They provide services $8 / 24$ hours per day, 5/7 days a weeks and focus on the establishment of partnerships in the community, district, region or national (see Table 9).

Table 9

Models of integrated home-base care service delivery

\begin{tabular}{|c|c|c|c|c|}
\hline $\begin{array}{l}\text { Criteria for } \\
\text { differentiation }\end{array}$ & Model A & Model B & Model C & Model D \\
\hline $\begin{array}{l}\text { Type of provided } \\
\text { service }\end{array}$ & \multicolumn{4}{|c|}{ Integrated home-based care services } \\
\hline $\begin{array}{l}\text { Form of } \\
\text { organization }\end{array}$ & Private (CSOs) & Private (CSOs) & Private (CSOs) & Private (CSOs) \\
\hline Human resources & $\begin{array}{l}\text { Doctor, medical } \\
\text { assistants }\end{array}$ & $\begin{array}{l}\text { Social workers, medical } \\
\text { assistants }\end{array}$ & $\begin{array}{l}\text { Doctor, medical } \\
\text { assistants, social } \\
\text { workers }\end{array}$ & $\begin{array}{l}\text { Medical assistants, } \\
\text { social workers, } \\
\text { psychologist, jurist }\end{array}$ \\
\hline Working mode & $\begin{array}{c}7 \text { hours per day } 5 \text { days a } \\
\text { week }\end{array}$ & $\begin{array}{c}\text { 7-8 hours per day } 5 \\
\text { days a week }\end{array}$ & $\begin{array}{c}\text { 7-8 hours per day } 5 \\
\text { days a week }\end{array}$ & $\begin{array}{c}\text { 7-8 hours per day } 5 \\
\text { days a week }\end{array}$ \\
\hline $\begin{array}{l}\text { Type of } \\
\text { beneficiaries }\end{array}$ & $\begin{array}{l}\text { Insured people, } \\
\text { uninsured people }\end{array}$ & $\begin{array}{l}\text { Uninsured people, } \\
\text { including without } \\
\text { identity documents, } \\
\text { vulnerable people that } \\
\text { have not reached the } \\
\text { retirement age }\end{array}$ & $\begin{array}{l}\text { Insured people, } \\
\text { uninsured people, } \\
\text { including without } \\
\text { identity documents, } \\
\text { vulnerable people that }\end{array}$ & $\begin{array}{l}\text { Insured people, } \\
\text { uninsured people, } \\
\text { including without } \\
\text { identity documents, } \\
\text { vulnerable people that }\end{array}$ \\
\hline
\end{tabular}




\begin{tabular}{|c|c|c|c|c|}
\hline $\begin{array}{c}\text { Criteria for } \\
\text { differentiation }\end{array}$ & Model A & Model B & Model C & Model D \\
\hline & & & $\begin{array}{l}\text { have not reached the } \\
\text { retirement age }\end{array}$ & $\begin{array}{l}\text { have reached the } \\
\text { retirement age }\end{array}$ \\
\hline $\begin{array}{l}\text { Criteria for } \\
\text { admission to } \\
\text { service }\end{array}$ & $\begin{array}{l}\text { Referral form (form no. } \\
\text { 027/e) from the family } \\
\text { doctor, specialist, doctor } \\
\text { employed by the } \\
\text { provider, case referral } \\
\text { from TUSA or LPA, } \\
\text { including patient's } \\
\text { individual request }\end{array}$ & $\begin{array}{l}\text { Based on the eligibility } \\
\text { criteria for care services } \\
\text { and the results of the } \\
\text { assessment of } \\
\text { applicant's care needs. } \\
\text { Referral mechanism } \\
\text { applied by TUSA, LPA, } \\
\text { other relevant } \\
\text { institutions. } \\
\text { Beneficiary's own } \\
\text { request or request from } \\
\text { his/her representative }\end{array}$ & $\begin{array}{l}\text { Referral form (form no. } \\
027 / \mathrm{e} \text { ) from the family } \\
\text { doctor, specialist, doctor } \\
\text { employed by the } \\
\text { provider, case referral } \\
\text { from TUSA or LPA, } \\
\text { including patient's } \\
\text { individual request. } \\
\text { Based on the eligibility } \\
\text { criteria for care services } \\
\text { and the results of the } \\
\text { assessment of } \\
\text { applicant's care needs. } \\
\text { Referral mechanism } \\
\text { applied by TUSA, LPA, } \\
\text { other relevant } \\
\text { institutions. } \\
\text { Beneficiary's own } \\
\text { request or request from } \\
\text { his/her representative }\end{array}$ & $\begin{array}{l}\text { Referral form (form no. } \\
\text { 027/e) from the family } \\
\text { doctor, specialist, doctor } \\
\text { employed by the } \\
\text { provider, case referral } \\
\text { from TUSA or LPA, } \\
\text { including patient's } \\
\text { individual request. } \\
\text { Based on the eligibility } \\
\text { criteria for care services } \\
\text { and the results of the } \\
\text { assessment of } \\
\text { applicant's care needs. } \\
\text { Referral mechanism } \\
\text { applied by TUSA, LPA, } \\
\text { other relevant } \\
\text { institutions. } \\
\text { Beneficiary's own } \\
\text { request or request from } \\
\text { his/her representative }\end{array}$ \\
\hline $\begin{array}{l}\text { The duration of } \\
\text { service provision }\end{array}$ & $\begin{array}{l}\text { 3-12 months till the } \\
\text { improvement of the } \\
\text { beneficiary's condition } \\
\text { or the occurrence of } \\
\text { circumstances that } \\
\text { makes the person } \\
\text { ineligible }\end{array}$ & Unlimited & $\begin{array}{l}\text { 3-6 months till the } \\
\text { improvement of the } \\
\text { beneficiary's condition } \\
\text { or the occurrence of } \\
\text { circumstances that } \\
\text { makes the person } \\
\text { ineligible }\end{array}$ & $\begin{array}{l}\text { 3-6 months, till the } \\
\text { improvement of the } \\
\text { beneficiary's condition } \\
\text { or the occurrence of } \\
\text { circumstances that } \\
\text { makes the person } \\
\text { ineligible }\end{array}$ \\
\hline $\begin{array}{l}\text { Area of service } \\
\text { delivery }\end{array}$ & Local / district & District & $\begin{array}{l}\text { Regional (more } \\
\text { districts) }\end{array}$ & $\begin{array}{l}\text { Regional (more } \\
\text { districts) }\end{array}$ \\
\hline $\begin{array}{l}\text { Cost of the } \\
\text { service paid by } \\
\text { the beneficiary }\end{array}$ & Free of charge & Free of charge & $\begin{array}{c}\text { Free of charge, symbolic } \\
\text { co-payment of the cost } \\
\text { of the service }\end{array}$ & Free of charge \\
\hline
\end{tabular}

Source: Author's analysis.

The development of these models has been possible due to funding from international donor agencies. All models address the vulnerable categories of beneficiaries, besides the referral from the family doctor and/or the specialist; they also need referral from the LPA, churches, and religious missions. It is important that 3 of the 4 models of the integrated home-based care services are accredited to provide medical services and contract medical visits from NHIC. Not less important is the fact that the 3 models render services for a period of 3 months (with the possibility to extend it up to 6 months or 1 year), which enables a rotation of the beneficiaries and delivery of services to a larger number of people requiring these services. In the favor of the integrated models are also the ways of fund allocation as well as the cost of the provision of services, which is lower, compared to the delivery of two separate components.

Peculiarities of the model A-integrated consists in the team of medical experts providing a limited range of social services. The services are delivered most often at the community level, sometimes in several villages from the district. Model B-integrated implies a team of social workers and medical assistants, providing services in district, but has no accreditation for the medical services rendered, respectively has no financing from NHIC, relying exclusively on the non-reimbursable external funds. This model stands out by offering the widest range of social services. We also point out that services are provided for an unlimited period of time. Model C-integrated implies a larger team of experts if compared to models A and B-integrated, based on the financial participation of LPA for the provision of services, including on a contribution from the beneficiary and renders regionally-based services. Model D-integrated implies the largest team of specialists (medical assistant, jurist, psychologist) providing services regionally. 
The main conclusion of the research is that the Republic of Moldova should define the position of home-based care services in the whole health and social system and the level of integration that should medical and social services achieve. Home-based care services should be placed as an intersection between the health care system and the social system or fully integrated. At this stage, it is necessary for the Ministry of Health, Labour and Social Protection to decide what organizational model will be chosen for the Republic of Moldova for the next decades as each of the models requires deeper reforms in other sphere of governance.

The assessment data allows us to come with some recommendations for the Ministry of Health, Labour and Social Protection representatives and other government authorities responsible for health and social policy development, LPA, but also home-based care providers: (i) to develop integrated home-based care services and a regulatory basis for this purpose, including a mechanism for cooperation between healthcare institutions, social services and CSOs to provide integrated services; (ii) to develop standard job descriptions that would outline the responsibilities of medical assistant and social worker in providing home-based care services; (iii) to develop policies for providers contracting visits for medical home-based care to meet the needs for these services at the national level; (iv) to continue partnerships with LPA and home-based care service providers; (v) to promote volunteering among home-based care service providers; (vi) to improve the access of vulnerable people to home-based care services by changing the Regulations on social home-based care services, to provide services to the elderly whose children live in other localities but have a poor family situation and are unable to help their parents.

\section{REFERENCES}

1. Home-based and long-term care. World Health Organization. Geneva, 1999 [Accesat 10.05.2018]. Disponibil: https://www.who.int/chp/knowledge/publications/home_based_and_ltc.pdf?ua=1

2. Home care in Europe. The solid facts. World Health Organization. Copenhagen, 2008. ISBN 978 9289042819.

3. The impact of ageing on public expenditure: projections for the EU-25 Member States on pension, healthcare, long-term care, education and unemployment transfers (2004-50). Economic Policy Committee and the European Commission. Brussels, 2006. [Accesat 15.12.2018]. Disponibil: https://publications.europa.eu/en/publication-detail/-/publication/9b3ed30f-ec24-4c498daf-03aa494242c2

4. THOME, Bibbi, DYKES, Anna-Karin. et. al. Home care with regards to definition, care recipients, content and outcome: systematic literature review. In: Journal of Clinical Nursing. 2003, vol. 12, pp. 860-872. [Accesat 27.01.2019]. Disponibil:

http://citeseerx.ist.psu.edu/viewdoc/download?doi=10.1.1.618.2796\&rep=rep1\&type=pdf

5. Home care across Europe. Current structure and future challenges. World Health Organization. Copenhagen, 2012. ISBN 9789289002882.

6. MELEIS, Afaf. Theoretical Nursing - Development and Progress. 3rd edition. New York, 1997.

7. THOME, Bibbi, DYKES, Anna et. al. Home care with regards to definition, care recipients, content and outcome: systematic literature review. In: Journal of Clinical Nursing. 2003, vol. 12, pp. 860872.

8. GENET, Nadine, BOERMA, Wienke, et al. Home care in Europe: a systematic literature review. In: BMC Health Service Research. 2011 [Accesat 22.03.2019]. Disponibil: https://bmchealthservres.biomedcentral.com/articles/10.1186/1472-6963-11-207

9. Hotărîrea Guvernului cu privire la aprobarea Programului unic al asigurării obligatorii de asistență medicală: nr.1387 din 10.12.2007. In: Monitorul Oficial al Republicii Moldova. 2007, nr. 198-202, art. 1443. [Accesat 07.05.2019]. Disponibil: http://lex.justice.md/index.php?action=view\&view=doc\&lang=1\&id=326302

10. Hotărîrea Guvernului pentru aprobarea modificărilor şi completărilor ce se operează în regulamentul cu privire la condiţiile de stabilire, modul de calcul şi de plată a îndemnizaţiilor pentru incapacitate temporară de muncă şi altor prestaţii de asigurări sociale. In: Monitorul Oficial al Republicii Moldova. 2014, nr. 9-13, art. 8. [Accesat 10.04.2019]. Disponibil: http://lex.justice.md/index.php?action=view\&view=doc\&lang=1\&id=351122

11. Data of the National Bureau of Statistics. [Accesat 16.02.2019]. Disponibil: http://statistica.gov.md/index.php?l=en 